\title{
THE NATURE OF PUBLIC RELATIONS IN VIETNAM
}

\author{
Van Thi Hong Loan \\ Ho Chi Minh City Open University
}

(Received: 20/05/2014; Revised: 18/06/2014; Accepted: 28/7/2014)

\begin{abstract}
Public relations is practiced around the world from Western to Asian countries. Public relations theory was initially defined and formalised in the United States of America, and continued to evolve in Europe and the United Kingdom, but had a slower uptake of theory and its application to practice in Asia and other parts of the world. Within varied social and cultural environments, this research explores public relations in Vietnam - what public relations performs in the context of Vietnam where the culture values personal relationships. The exploratory study uses a qualitative research approach with the primary method of semistructured interviews of twenty-nine consultants and in-house public relations practitioners, in both Vietnamese and international organisations. The research found that Vietnamese public relations uses a one-way communication model proposed by Grunig \& Hunt (1984). It simultaneously uses a two-way shared perspective which appears similar to the symmetrical model by Grunig \& Hunt (1984) but the Vietnamese model focuses on relationships for communication. The study concludes that the nature of public relations in Vietnam is changed by the impact of the cultural factors.
\end{abstract}

Keywords: Public Relations, Personal Relationships, Favour, One-way Communication, Two-way Shared Perspective.

\section{Introduction}

Public relations (PR) activities are now conducted in transnational organisations in many countries. As the number of PR consultancies and organisations outside Western countries is increasing, and the knowledge of public relations is applied in different countries, international practitioners face different challenges (Sriramesh \& Verčič, 2009). Scholars stated that although current theory is still a foundation for international public relations, it needs to be broadened and reconstructed to best meet the status and development of public relations approaches of different countries (L'Etang \& Pieczka, 1996, 2006). Wakerfield (2008), for example, posited that the existing theory of public relations is 'an essential foundation for international public relations, but... need(s) to reconstruct the theory in light of changes in certain variables' (p. 153). Other scholars moreover emphasised that it is time to extend existing public relations theory, and develop additional theories for public relations in different regions of the world (Botan \& Hazleton, 2006).

Nevertheless, there is still a lack of empirical data on public relations practice in many Asian countries that might broaden the theory of public relations (Sriramesh \& Verčič, 2009). The review of the literature indicates that research on public relations in Asian countries, in particular Vietnam, is bourgeoning but much of that research is in the early stages of development. Vietnam today is integrating into the world economy (Nguyen Khac Vien, 2009). After the Đổi Mới policy by the Vietnamese government in 1986, the economy of Vietnam has changed from a centrally-planned to a market-based economy. 
Many international organisations have thus come to Vietnam to set up their business, and brought their public relations knowledge with the aim to apply the core public relations principles to Vietnam. The author of this article thus wonders whether theories of public relations such as Grunig \& Hunt's (1984) models of public relations can be applied in Vietnam, and which considerations need to be taken into account?

\section{Background to professional public relations in Vietnam}

After the Đổi Mới, the first domestic consultancies such as Public Relations BiCultural Consulting or PUBCOM were established in 1995 in Hanoi, and Max Communications commenced in 1997 at Ho Chi Minh City (McKinney, 2000). John Baily \& Associates from Australia, Ogilvy Public Relations (part of the Ogilvy \& Mather advertising, marketing and public relations firm owned by the WPP Group), Leo Activation (Leo Burnett), and JWT Vietnam (J. Walter Thompson) were four of the first international consultancies to provide public relations services in Vietnam in the mid-1990s (Van Thi Hong Loan, 2011). Clients of these consultancies have mainly been international business corporations such as Nestlé and Dutch Lady (dairy products). However, some clients left them for Vietnamese consultancies due to cheaper fees and the ease of business agreements. Some international consultancies then withdrew from the market because of a failure to compete with local consultancies, and an insufficient understanding of how to carry out effective public relations in Vietnam. Cooperation with a local consultancy might be a good solution. One of the first joint ventures between a local PR firm, T\&A Communication, and an international firm, Ogilvy \& Mather was set up in 2009. More recently in 2012 Edelman, the world's largest PR firm has established a partnership with AVC, a Vietnamese PR consultancy (Van Thi Hong Loan, 2014).

The number of consultancies and firms which provide public relations services in recent years is increasing, especially after
Vietnam joined the World Trade Organization (WTO) in 2007. Compared with 11 PR firms in 2006 (McKinney, 2006), the number of consultancies providing PR services reached 300 by 2008 (Nguyen Thanh Son, 2008); however, there was only 20 professional PR firms - they have a PR focus rather a marketing focus (FTA Market Research, 2010). One explanation is that, due to the increasing need for public relations in the changing and rapidly expanding markets, many other business sectors, including advertising, moved into public relations sector and set up firms. According to General Statistics Office of Vietnam (2011), foreign direct investment (FDI) in Vietnam reached a peak of more than US\$71 million in 2008, a year after joining WTO-six times greater compared with 2006. Public relations in Vietnam is mainly used by foreign organisations (Stanton, 2009) so, the FDI statistics imply that the high number of PR consultancies set up in 2008 was to meet market demand. Nevertheless, in the first 20 leading PR consultancies in Vietnam, there was only one joint-venture, between Vietnamese and American consultancies; the rest were domestic consultancies. This surveyed 150 business people in Vietnam who used public relations services in agencies in 2009 (FTA Market Research, 2010). The majority of international PR consultancies in Vietnam have come from the United States and Australia. FTA Market Research's results for 2010 imply that domestic consultancies provide public relations services that are more appropriate than international consultancies. The practice of Vietnam challenges international consultancies. The nature of public relations in Vietnam may be different to that in Western countries.

\section{Research aims}

My research will explore the nature of public relations in a country where the culture emphasises personal relationships in both private life and business exchanges (Little \& Reed, 1989) - these are carried out differently to those in the practice of public relations in the United States, the United Kingdom and 
Australia, where relationships are important but they do not have the extent of personal influence that seems apparent in Vietnam (Tran Ngoc Them, 1999, 2004). The characteristics of the culture that are peculiar to Vietnam are explored to shed some light on what might make public relations practice different for international public relations consultancies that at times challenges their practice, and in the case of personal relationships to work with media peopleresulting in the consultancy moving out of Vietnam. The main questions relating to the nature of public relations will be specified as follows:

(1) What is the nature of public relations in Vietnam?

(2) Which local considerations need to be taken into account?

\section{Literature review}

Based on observations of practice in the United States, Grunig \& Hunt (1984) developed four models of public relations including press agentry/publicity, public information, two-way asymmetrical model, and two-way symmetrical model which typify public relations strategies and techniques at the organisational level. The four models of public relations are based on two criteria: purpose of communication and nature of communication. For the first criterion-purpose of communication, as an organisation practices an asymmetrical model, public relations tends to be used to manipulate the publics for its benefit. On the contrary, an organisation with the symmetrical view often changes its behaviour based on the demand of its publics. For the second criterion-the nature of communication, an organisation can conduct one-way models (press agentry/publicity and public information) through disseminating messages to its publics without seeking any feedback. In contrast, an organisation can choose to practice two-way models (two-way asymmetrical and two-way symmetrical models) through seeking information from its publics (i.e. attitudes of its publics toward the organisation).
The characteristics of the four models of public relations are described in detail as follows:

- Public relations practitioners of the first model use persuasion and manipulation to influence their publics according to the wishes of their organisation. There is no dialogue between the organisation and its publics in this model. Its primary goal is to put its view towards its publics through media and other channels. Practitioners highlight the positive aspects of their organisation and often try to downplay negative information about their organisation to the extent of misleading their publics. The first model is 'propagandistic' because it 'manipulates' publics (Moloney, 2006; Grunig et al., 1995).

- In the second model, practitioners tend to spread accurate, but often favourable information to their publics. Compared to the first model, the second tends to disseminate truth and factual information to publics. Its main purpose is to inform rather than manipulate.

- Public relations practitioners of the twoway asymmetrical model undertake research to find out how to persuade their publics as the organisation desires. The significance of this model is that an organisation seeks information about the attitude of its publics towards it before communicating messages to them. Practitioners in this model do not volunteer to change their organisation's behaviour even though their public relations programs support their publics (Grunig \& Hunt, 1984).

- In the last model-two-way symmetrical model, practitioners use research and communication to understand their publics, resolve a possible conflict and build a respect and mutual understanding between their organisation and publics. Public relations practitioners in the symmetrical model use communication for relationships with their publics (this point 
will be considered in my research). For mutual understanding, an organisation not only persuades its publics but also rethinks its activities and changes its own behaviour. The two-way symmetrical model is a requirement of public relations excellence (Grunig \& Grunig, 1992), that 'individuals, organizations, and publics should use communication to adjust their ideas and behaviour to those of others rather than to try to control how others think and behave' (Grunig, 2006, p. 156). However, this model has received debate because of its focus on the ideal rather than its reflection of the reality of public relations practice in terms of 'sharing (organizations)'s power' with their publics (Van der Meaden, 1993, cited in Wakefield, 2008, p. 148). There is often an imbalance between parties and organisations, for example, may have most of the power - to be symmetrical and practice two-way communication for mutual benefit is very difficult to achieve as there are often many points of view to be considered. This model describes how public relations should be practiced rather than how it is actually practiced.

Each model of public relations can be used to contribute to the efficiency of an organisation according to its 'structure' and the 'nature of its environment' (Grunig, 2001, p. 12). However, the two-way symmetrical model, or a combination of the two-way symmetrical and two-way asymmetrical models (also called the Mixed-motive model) is purported to be the most effective model of public relations for the success of organisations. To reach the two-way symmetrical destination, public relations practice firstly moves from one-way asymmetrical communication, "with complete truth not essential', through one-way symmetrical with 'truth important', and twoway asymmetric, whose purpose was 'scientific persuasion' with imbalanced effects (Grunig \& Hunt, 1984, p. 22). In terms of the mixed motive model, practitioners pursue their own organisations' interests and simultaneously help their publics' interests.
Although Grunig \& Grunig (1992) confirmed that the mixed-motive model, following the research by Murphy (1991), is a version of the symmetrical model, Murphy (1991), other scholars (e.g. Plowman, 1998, 2007; Stokes, 2010) argued that the mixed motive model might describe what is happening in reality rather than the two-way symmetrical model. It reflects the adaptive nature of communication.

When Grunig \& Hunt's (1984) theory was applied to non-Anglo cultures, for example, in India (Sriramesh \& Grunig, 1988; Sriramesh, 1992, 1996), and China (Chen \& Culbertson, 2009), scholars discovered that practitioners in these countries also used other models to conduct their public relations. There are more than the four models of public relations proposed by Grunig \& Hunt (1984). For example, scholars (e.g. Grunig et al., 1995; Sriramesh et al., 1999) found that personal influence model which is used in public relations in countries such as India, Japan, and Korea. Public relations in China is strongly impacted by this model (see, e.g. Chen, 1996; Chen \& Culbertson, 2009). This model points out that the success of public relations is greatly influenced by personal networks. Public relations practitioners used interpersonal communication to build personal influence/personal relationships with important individuals and leaders, especially the media and governmental people. Many practitioners, for instance, used hospitality relations such as giving gifts and hosting dinners for persons from whom they could later claim 'return favours'. Grunig, the author of the four models of public relations did acknowledge this model (see, e.g. Grunig et al., 1995, Grunig, 2001), but the Asian context is not fully explicated, and his view about this model may be controversial as he stated that it is only a 'variation', or 'pattern of practice' in relation to the four models (Grunig, 2001, p. 12). Referring to a 'variation' to the four models seems to pass over some of the important practices that shape public relations practice in different cultures and reflects the characteristics of Asian culture, in particular the Confucian Asian culture such as the Chinese culture (see, e.g. Hwang, 1987). It 
seems to be similar in Vietnam in terms of personal networks and personal relationships with media people. My research considers the personal influence model as part of the focus on relationships and their role in public relations practice.

\section{Research methodology and method}

Research relating to exploring the nature of public relations which includes issues of public relations in practice and influences of social environment on them can be undertaken through quantitative and qualitative approaches. However, it became evident in the literature review that for research regarding the models of public relations, quantitative approaches in this realm faced many limitations (Sriramesh, 2009; Stack \& Watson, 2007). A quantitative approach 'emphasizes the measurement and analysis of casual relationship between variables, not process' (Denzin \& Lincoln, 2003, p. 13). The quantitative approach was not a best choice for my research which explored the practice of public relations in a specific context (Vietnam) where scholarship is emerging, there are few public relations professionals, and the socialcultural environment is not simple. Quantitative analysis is useful in gaining an overall understanding of trends but positivism and its focus on measurable results is difficult at this stage where so little research is known about Vietnamese public relations, and where public relations is conducted in the challenging environment - it needs to be explicated thoroughly. The qualitative approach was the most appropriate one for this study which strongly focuses on the emerging practice of the field and explores what is happening in public relations in Vietnam.

\section{Semi-structured interviews}

The qualitative study allowed an understanding of the Vietnamese context within which respondents (i.e. consultants and in-house practitioners) act, and of influences that this context had over their action. The strength of a qualitative study is that it gets at processes that lead to outcomes (Patton, 1990; Creswell, 1994) and identifies them in a specific setting. The qualitative interview study was employed to find out research participants' thoughts, belief and feelings in their world (Berger, 2000; Babbie, 1998; Lee, 1999). Their world was then studied and interpreted through their perceptions and viewpoints about public relations and its current practice and impacts on their public relations programs and campaigns.

The semi-structured interview methods permitted interviewees to freely express their opinions and experiences. The aim of the qualitative interviews is to understand 'the social actor's experience and perspective through stories, accounts, and explanations' (Lindlof \& Taylor, 2002, p. 173). In this study, the interviewer explored how public relations does in practice. Interviewing allowed the researcher to find out professional realities which the consultants and practitioners faced in their practice, and identify local cultural factors which influence the way they perform public relations. Through the qualitative interviews, the researcher and interviewees had the opportunities to exchange knowledge and beliefs, and to clarify some interview questions which previously were not fully understood by research participants. The interviews moreover gave opportunities for the interviewer and interviewees to elucidate terms and assumptions which might be different to both parties. This approach also allowed the researcher to understand terms in the field to be interpreted by each research participant which might not be the same as the interviewer's knowledge and understanding.

\section{Sampling}

Data for the research was gathered from eight consultancies: four international consultancies that were operating in Vietnam, and four Vietnamese consultancies that were classified as specialised public relations ones in Vietnam according to FTA's (market research company) survey in 2010 (FTA Market Research, 2010). All the consultancies' main offices were located in Ho Chi Minh City, the biggest city in Vietnam. A half of the consultancies also had offices in Hanoi, the capital and second biggest city in Vietnam. In 
Vietnam, most public relations consultancies set up their offices in the two biggest cities so the sample of public relations consultancies in my research reflected the general picture of public relations consultation in Vietnam. The researcher also chose in-house public relations practitioners in seven international and Vietnamese companies as part of the sample in order to provide a better understanding of the nature of public relations.

Twenty-nine research participants including twenty-two consultants and seven in-house public relations practitioners took part in this research. Of the twenty-nine participants, there were twenty-six Vietnamese nationals and three internationals that were from the United States, Australia and Philippines. In each consultancy, two to three consultants were approached to interview. Consultants in this study included consultants, senior consultants and chief executive officers (CEOs). All of them were interviewed through face-to-face, semi-structured interviews. The interviews were conducted in the language preferred by the research participants (i.e. English or Vietnamese). The duration for each interview was from forty to ninety minutes for the schedule of interviews.

\section{Data analysis}

The process of qualitative data analysis means changing raw data to 'evidence-based interpretations' (Rubin \& Rubin, 2005, p. 201). This includes 'classifying, comparing, weighing and combining material from the interviews to extract the meaning and implications, to reveal patterns, or to stitch together descriptions of events into a coherent narrative' (p. 201). In this research, the data analysis consisted of coding, identifying and developing categories and themes found in the data for later interpretation. This study tends to use category for 'the descriptive level of coding', and theme for describing 'integrating, relational ideas' that are generated from the data.
The researcher used manual analysis and qualitative data analysis software Nvivo version $8.0^{1}$ which is an information management software package designed for use in qualitative research. The researcher used this software to assist in the analysis of the data because it is supported to electronically archive, and organise categories into hierarchies for easy approach, re-visiting, and re-examination of the data. The data was stored and managed through Nvivo version 8 . Nvivo 8 allows my research to retrieve, fill and search the data rapidly during the process of data analysis. However, the researcher recognized that this software did not 'do the analysis for the researcher' because the researcher had to 'create the categories, do segmenting and coding, and decide what to retrieve and collate' (Basit, 2003, p. 145), generate themes from the ideas of the respondents and produce theoretical understanding.

\section{Findings and discussion}

Grunig \& Hunt's (1984) theory stressed that there are four models of public relations in practice: press agentry/publicity, public information, two-way asymmetrical and twoway symmetrical model. They then developed the mixed motive model, combined a two-way asymmetrical and symmetrical model, to extend the two-way symmetrical model. The findings of my research indicate that public relations in Vietnam reflects aspects of the first and second model proposed by Grunig \& Hunt (1984). Nevertheless, there is no evidence found in my research that reflects the mixed motive and symmetrical model offered by Grunig \& Hunt (1984). Public relations in Vietnam uses a two-way model, but communication is not the first priority in this model, it is the relationship. The setting up of the relationship includes having a detailed and personal knowledge of journalists, for example, so that personal aspects of the relationships become important to the business of the relationship. This differs in certain

\footnotetext{
${ }^{1}$ Nvivo is a qualitative data analysis computer software package produced by QSR International, see at http://www.qsrinternational.com/products nvivo.aspx
} 
aspects in the two-way symmetrical and mixed-motive models by Grunig \& Hunt (1984) where a business relationship has greater emphasis.

\section{One-way communication}

Grunig \& Hunt (1984) contended that practitioners in the first model of public relations (press agentry/publicity) highlight the positive aspects of their organisation, or products and transfer non-factual information to their publics. Public relations in the first model tends to be propagandistic because it manipulates their publics for their benefits (Grunig et al., ; Moloney, 2006). In contrast, in symmetrical models, organisations often change their behaviour based on the demand of their publics, and this model has been viewed as the most ethical in public relations practice (Grunig \& Hunt, 1984). My research data shows that public relations in Vietnam has a strong emphasis on marketing and promotion reflecting a one-way process of communication. From sixty to seventy percent of respondents in my research stressed that the purpose of public relations is to promote products. In addition, reflecting the marketing perspective, more than a half of respondents said they attempt to 'hide' problems regarding their products. They are not keen for the media to be informed about their faulty products. This suggests that it is not only one-way but it is selected for promotional purposes-it is certainly not based on engagement with the public, or to inform the public, it is about marketing products for organisations.

The respondents moreover stated that they always send the media the best and most favourable information about their products or organisation, and tend to avoid media exposure about their faulty products. Journalists help them to publish favourable information about their products, to highlight their favourable information and reduce unfavourable information. If the media publish negative information about their faulty products, public relations practitioners tend to use personal relationships with a journalist who is in their network to reduce the unfavourable information about their faulty products and organisation. This is a good example of the relationship affecting the communication. They try to downplay negative information about their products and organisation which is seen to be misleading their publics. They use manipulation in their public relations because of the benefits to the organisation.

Currently, public relations in Vietnam tends to be propagandistic. Additionally, public relations practitioners often use their relationships with media people to manipulate media agendas such as editorials for their publics according to their organisation's desires. These results corroborate Grunig \& Hunt's (1984) theory about the press agentry/publicity model (the first model) of public relations, but they also indicate that the practice of propaganda is open, and is seen as part of the way things are done in Vietnam. It is a point of discomfort for international public relations consultants who did not listen to the advice of their Vietnamese staff, and acted in a way that was appropriate to their culture but that is not the way Vietnamese public relations was practised.

Nearly half of the participants in my research reported that they want to focus on reporting all aspects of products rather than 'hide' their problems. They tend to disseminate truth and factual information rather than manipulate their publics. Moreover, they stressed that more international companies, rather than Vietnamese companies, tend to tell the truth and report their problems related to faulty products. These findings are consistent with Grunig \& Hunt's (1984) public information model (also called the second model of public relations), in which practitioners tend to disseminate accurate information. Hence, public relations in Vietnam not only uses the first model, but also the second model of public relations where there is every intention to carry out public relations activities, such as honest information, even if it is regarding a faulty product.

To summarise, the data indicated that public relations in Vietnam has a strong focus 
on marketing. The initial findings showed that it tends to conduct one-way communication, and its purpose is to promote products rather than manage an organisation's reputation. There is a monologue from organisations to their publics. Its aim is propaganda and dissemination of information mainly for marketing purposes. For half of the respondents in my research, truth and the need to give details about products, even when they are faulty, is not important but to the other half, truth is important in distributing information and products to their publics. For all practitioners, mass media are means of communication between organisations and their publics as part of communication to, rather than with the publics (Figure 1). Organisations use communication to build relationships with their publics, but on a oneway basis. This one-way communication is consistent with the first and second of the models offered by Grunig \& Hunt (1984).

\section{Figure 1. One-Way Communication (Adopted from Grunig \& Hunt's (1984) theory)}

\section{Organisations}

\section{Two-way shared perspective}

The study findings indicate that practitioners in Vietnam seem to use the personal influence model which was also found in many Asian countries such as South Korea, Japan and India (Sriramesh et al., 1999), and Taiwan (Huang, 2000). These researchers such as Sriramesh (1999) and Huang (2000) found that in this model, practitioners tend to use their efforts to build and maintain close and personal relationships with their key publics. The success of public relations is greatly influenced by personal networks. According to these researchers, in this model practitioners often use gifts and dinners for individuals (e.g. journalists) from whom they could later demand return favour, such as putting PR articles on newspapers as PR practitioners want. There are similarities between these studies and my research about these practices. The research reported here shows that public relations practitioners in Vietnam use personal influences to build and develop the connection with their target publics in order to get what they want. This relationship affects what is communicated to the public. They use tips and gifts to control their public relations messages to the media, and to influence media agendas which are designed by journalists.
Mass Media $\longrightarrow$ Publics

Nevertheless, public relations in Vietnam does much more than that. Public relations practitioners in Vietnam not only use their personal relationships to communicate and influence their target publics such as journalists but these individuals (e.g. journalists) also use their resources such as media information as favour to inform and consult public relations practitioners about public relations articles. That means journalists and media people use their resources to communicate with public relations practitioners. There is mutual understanding between public relations practitioners and journalists through the personal relationships. My literature review shows that this issue has not been mentioned in research, especially research in Asian countries such as Japan and India (Sriramesh et al., 1999), where personal relationships are important in public relations. This means there is evidence of the use of favour for journalists by public relations practitioners, but there is so little understanding of that for public relations practitioners by journalists. My data also shows that journalists are willing to use favour, to inform public relations practitioners about public relations articles appearing in a newspaper, and it is an expectation of both parties that this sharing takes place.

Clearly, the collaboration between public 
relations practitioners and journalists is effective. Public relations practitioners in Vietnam seem to conduct effective public relations through the information exchange, dialogue exchange and relationship building between them and journalists. Both organisations and journalists exchange news and information in the same way to conduct public relations. Public relations in Vietnam seems to use a quasi-symmetrical communication model. This means its appearance looks like the two-way symmetrical communication proposed by Grunig \& Hunt (1984) but its practice is not so. There is an exchange between public relations practitioners and journalists before, and after conducting public relations (e.g. constructing public relations plans). Before public relations programs, public relations practitioners exchange information with journalists, or news media to have effective public relations. After public relations programs, journalists inform public relations practitioners about their public relations effectiveness in the media (e.g. when public relations editorials are published in mass media). Underpinning what looks like one-way mass media communication is a rich source of relational exchange, and respect amongst journalists and media people. I thus suggest that organisations use relationships with journalists and media people first, and then use mass media for communication (Figure 2).

Figure 2. Two-Way Shared Perspective (Van Thi Hong Loan, 2014)

\section{Organisations}

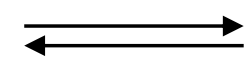

\section{The nature of public relations}

According to Grunig \& Hunt (1984), in a symmetrical model and its version-a mixed motive model, practitioners (in the West) use communication to understand their publics and build mutual understanding between organisations and their publics. They use negotiation to manage conflicts and use mediation to satisfy their publics' interests. However, because of a strong focus of relationships in Vietnam, it is the relational context that is the key for practitioners in Vietnam. Practitioners in Vietnam use relationships to communicate and build mutual understanding with their strategic publics. Communication is facilitated by relationships. Practitioners in Vietnam use relationships for communication whereas public relations in Western countries use communication for relationships, although in each of these models, the relational focus is recognised and

\section{Publics $\longrightarrow \quad$ Mass Media}

understood. At this point, the symmetrical communication model and its version-the mixed motive model - may be appropriate in Western settings rather than in Vietnam.

Reflecting marketing perspectives, public relations in Vietnam uses the one-way asymmetrical communication to communicate and then build relationships with their publics. Reflecting characteristics of the Vietnamese culture, public relations in Vietnam uses the two-way shared perspective to build relationships and then communicates with strategic publics such as business managers, but in particular with news media. Based on the findings of the research, a chart is suggested that shows the nature of public relations in Vietnam-disseminating messages without seeking any feedback from organisations' publics, but exchanging information with target publics such as journalists (Figure 3). 
Figure 3. The nature of public relations in Vietnam (Van Thi Hong Loan, 2014)

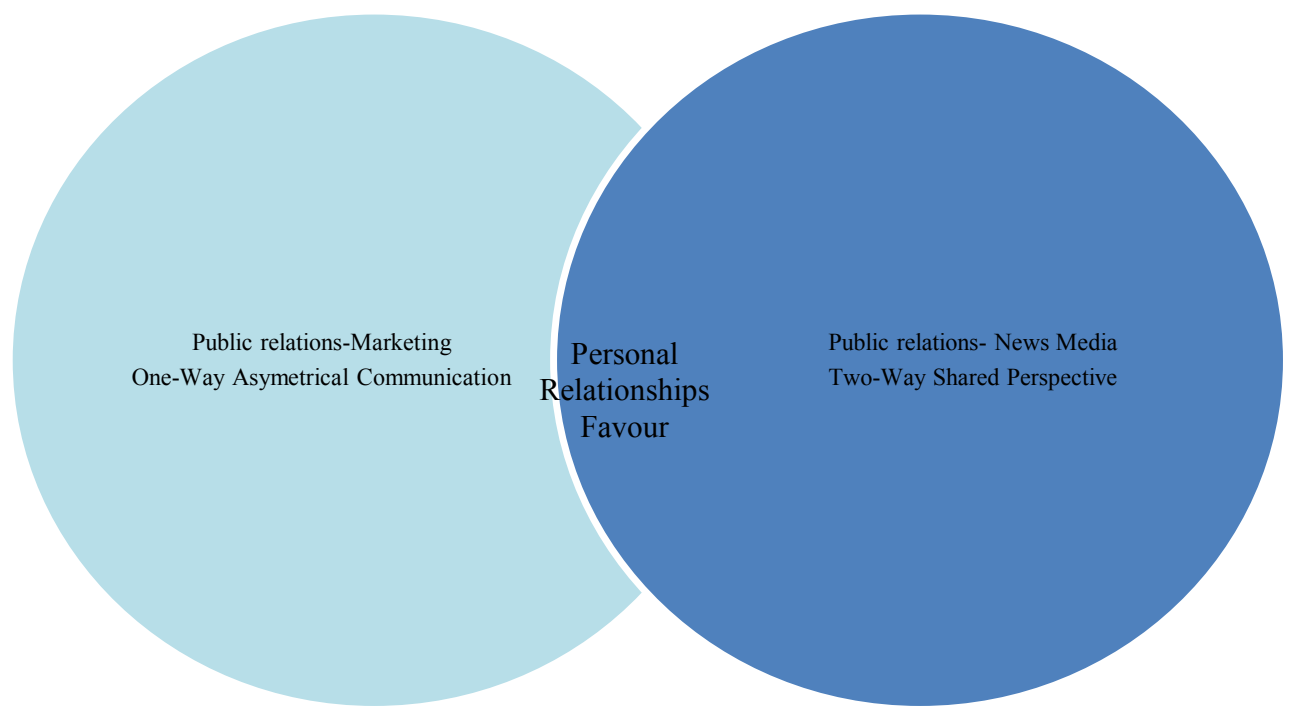

Clearly, the two-way shared perspective which is used by public relations in Vietnam looks a little different from the Grunig \& Hunt's (1984) models. It is created by the influence of Vietnamese culture. The influence of culture on the relationship between media people and PR practitioners was studied in research such as Berkowitz \& Lee's (2004) study, as Cheong, a characteristic of Korean culture which helps media relations and information exchanges between them to be effective. Nevertheless, my research highlights that PR practitioners and journalists in Vietnam exchange not only information through dialogue, but also consultation to help each other towards the aim of public relations. The research findings suggest that there are local nuances such as personal relationships and favour which influence the way to conduct public relations.

Scholars such as Sriramesh \& Verčič (2009) argued that the models of public relations and the theory arising from them have not focused on local nuances and Asian contexts. Grunig \& Hunt (1984) emphasised that their four models capture the essence of public relations activities that are typically practiced by most organisations in the world. However, the study indicates that the Grunig \& Hunt's (1984) models and public relations theory have not fully reflected cultural characteristics in international settings such as Vietnam, even though aspects of the models have relevance. The use of favour and personal relationships in public relations in Vietnam is similar to that in China. But the two-way shared perspective between $\mathrm{PR}$ and news media, which this study found, has not yet showed in world literature.

\section{Conclusion}

This article provides evidence to point that a different cultural setting can change the nature of public relations. The findings contribute to this argument in the context of Vietnam; this helps with the development of the emerging theory of public relations. Grunig \& Hunt (1984) recognised, but has not emphasised local nuances in non-Western countries as they developed their theory of public relations. There has been a suggestion that the theory offered by Grunig \& Hunt (1984) need to be broadened because it has not described other models (Holtzhausen et al., 2003), such as the two-way shared perspective. The evolution of public relations in Vietnam supports the body of knowledge of international public relations in particular Asian public relations which begun research into their origins recently. The characteristics of public relations practice in Vietnam influence re-theorization or lead to new theory in the future. 


\section{REFERENCES}

Babbie, E. (1998). The practice of social research, Belmont, Wadsworth Publishing.

Basit, T. N. (2003). Manual or electronic? The role of coding in qualitative data analysis. Educational Research, 45, 143-154.

Berger, A. (2000). Media and communication research methods: An introduction to qualitative and quantitative approaches, Thousand Oaks, Sage Publications.

Berkowitz, D. \& Lee, J. (2004). Media relations in Korea: Cheong between journalists and public relations practitioners. Public Relations Review, 30, 431-437.

Botan, C. H. \& Hazleton, V. (2006). Public relations in a new age. In: Botan, C. H. \& Hazleton, V. (eds.) Public relations theory II. Mahwah, New Jersey: Lawrence Erlbaum Associates.

Chen, N. (1996). Public relations in China: The introduction and development of an occupational field. In: Culbertson, H. M. \& Chen, N. (eds.) International public relations: $A$ comparative analysis. Mahwah, New Jersey: Lawrence Erlbaum Associates.

Chen, N. \& Culbertson, H. M. (2009). Public relations in mainland China: An adolescent with growing pains. In: Sriramesh, K. \& Verčič, D. (eds.) The global public relations handbook: Theory, research, and practice. New York and London: Routledge.

Creswell, J. W. (1994). Research design: qualitative and quantitative approach, Thousand Oaks, California, Sage.

Denzin, N. \& Lincoln, Y. (2003). The Landscape of Qualitative research, Theories and Issues, Thousand Oaks, California, Sage Publications Inc.

FTA Market Research. (2010). Advertising and PR trends in 2010: PR agency aided awareness [Online]. TP. HCM: FTA Market Research. Available: http://www.slideshare.net/leminhhai/advertising-and-pr-usage-trend-2010 [Accessed 16 January 2010].

General Statistics Office of Vietnam. (2011). Foreign direct investment projects licensed in period 1998-2011 [Online]. Hanoi: General Statistics Office of Vietnam. Available: http://www.gso.gov.vn/default_en.aspx?tabid=471\&idmid=3\&ItemID=13121 [Accessed 10th January 2013].

Grunig, J. (2001). Two-way symmetrical public relations: Past, present and future. In: Health, R. L. (ed.) Handbook of public relations. Sage Publications.

Grunig, J. (2006). Furnishing the edifice: Research on public relations as a strategic management function. Journal of public relations research, 18, 151-176.

Grunig, J. \& Grunig, L. (1992). Models of public relations and communication. In: Grunig, J. (ed.) Excellence in public relations and communication management. Hillsdale, New Jersey: Lawrence Erlbaum Associates.

Grunig, J., Grunig, L., Sriramesh, K., Huang, K. \& Lyra, A. (1995). Models of public relations in an international setting. Journal of Public Relations Research, 163-86.

Grunig, J. \& Hunt, T. (1984). Managing public relations, Fort Worth, Harcourt Brace.

Holtzhausen, D., Petersen, B. \& Tindall, N. (2003). Exploring the myth of the symmetrical/asymmetrical dichotomy: Public relations models in the new South Africa. Journal of Public Relations Research, 15, 305-341. 
Huang, Y. H. (2000). The personal influence model and gao guanxi in Taiwan Chinese public relations. Public Relations Review, 26, 219-36.

Hwang, K. (1987). Face and favor: The Chinese power game. American Journal of Sociology, 92, 944-974.

L'Etang, J. \& Pieczka, M. (1996). Critical perspectives in public relations, London, International Thomson Business Press.

L'Etang, J. \& Pieczka, M. (2006). Public relations: Critical debates and contemporary practice, Mahwah, New Jersey., Lawrence Erlbaum Associates.

Lee, T. W. (1999). Using qualitative methods in organizational research, Thousand Oaks, Sage Publications.

Lindlof, T. R. \& Taylor, B. C. ( 2002). Qualitative communication research methods, Thousand Oaks, SAGE Publications.

Little, R. \& Reed, W. (1989). The Confucian renaissance, Annandale, N.S.W., Federation Press.

McKinney, B. (2000). Public relations in the land of the ascending dragon: Implications in light of the U.S./Vietnam bilateral trade agreement. Public Relations Quarterly, 45, 23-26.

McKinney, B. (2006). Public relations in Vietnam: A six-year perspective. Public Relations Quarterly, 51, 18-22.

Moloney, K. (2006). Rethinking public relations: PR propaganda and democracy, London and New York, Routledge.

Murphy, P. (1991). The limits of symmetry: A game theory approach to symmetric and asymmetric public relations. Public Relations Research Annual, 3, 115-131.

Nguyen Khac Vien (2009). Vietnam: A long history, Hanoi, Vietnam, The Gioi Publishers.

Nguyen Thanh Son. (2008). P.R.--Một nghề đang hấp dẫn giới trẻ hiện nay (P.R. - A job is attracting young people today) (in Vietnamese). [Online]. Ho Chi Minh City, Vietnam. Available: $\quad$ http://thptlynhan-hanam.edu.vn/forum/viewtopic.php? $\mathrm{f}=52 \& \mathrm{t}=1918$ [Accessed 10th May 2009].

Patton, M. Q. (1990). Qualitative evaluation and research methods, Newbury Park, California, Sage.

Plowman, K. D. (1998). Power in conflict for public relations. Journal of public relations research, 10, 237-258.

Plowman, K. D. (2007). Public relations, conflict resolution, and mediation. In: Toth, E. L. (ed.) The future of excellence in public relations and communication management. Mahwah, New Jersey: Lawrence Erlbaum Associates.

Rubin, H. J. \& Rubin, I. S. (2005). Qualitative interviewing: the art of hearing data, Thousand Oaks, California., Sage Publications.

Sriramesh, K. (1992). Societal culture and public relations: Ethnographic evidence from India. Public Relations Review, 18, 201-211.

Sriramesh, K. (1996). Power distance and public relations: An ethnographic study of Southern Indian organizations. In: Culbertson, H. M. \& Chen, N. (eds.) International public relations: A comparative analysis. Mahwah, New Jersey: Lawrence Erlbaum Associates.

Sriramesh, K. (2009). The relationship between culture and public relations. In: Sriramesh, K. \& Verčič, D. (eds.) The global public relations handbook: Theory, research and practice. 
Expanded and revised edition ed. New York and London: Routledge.

Sriramesh, K. \& Grunig, J. (1988). Toward a cross-cultural theory of public relations: Preliminary evidence from India. Paper presented to the panel on New Frontiers in the International Management Environment. Myrtle Beach, North Carolina: Association for the Advancement of Policy, Research and Development in the Third World.

Sriramesh, K., Kim, Y. \& Takasaki, M. (1999). Public relations in three Asian cultures: An analysis. Journal of Public Relations Research, 11, 271-292.

Sriramesh, K. \& Verčič, D. (2009). The global public relations handbook: Theory, research, and practice, New York, Routledge.

Stack, D. W. \& Watson, M. L. (2007). Two-way communication based on quantitative research and measurement In: Toth, E. L. (ed.) The future of excellence in public relations and communication management: Challenges for the next generation. New Jersey: Lawrence Erlbaum Assocates.

Stokes, A. (2010). Activism and the limits of symmetry: The public relations battle beween Colorado GASP and Philip Morris. Journal of Public Relations Research, 22, 26-48.

Tran, Ngọc Them (1999). Co sở văn hóa Việt Nam (Basic Understanding of Vietnamese Culture), Vietnam, Giáo dục Publisher.

Tran, Ngoc Them (2004). Tìm về bản sắc văn hóa Việt Nam, Tp. Hồ Chí Minh, Tổng hợp Thành phố Hồ Chí Minh

Van Thi Hong Loan (2011). Public relations in Vietnam: History in the making. In: Watson, T. (ed.) The proceedings of the International History of Public Relations Conference 2011. Dorset, United Kingdom: Bournemouth University.

Van Thi Hong Loan (2014). Vietnam. In: Watson, T. (ed.) Asian Perspectives on the Development of Public Relations: Other Voices. Palgrave Macmillan, United Kingdom.

Wakefield, R. I. (2008). Theory of international public relations, the Internet, and activism: A personal reflection. Journal of public relations research, 20, 138-157. 